\title{
Applications of Botulinum Toxin at a Neurology Clinic: An Eleven-year Experience
} Bir Nöroloji Kliniğinde Botulinum Toksini Uygulamaları: On Bir Yıllık Deneyim

\author{
Hasan Rifat Koyuncuoğlu, Seden Demirci \\ Süleyman Demirel University Faculty of Medicine, Department of Neurology, Isparta, Turkey
}

\section{Summary}

Objective: The aim of this study was to report our experience with Botulinum toxin (BoNT) in the treatment of various neurologic conditions. Materials and Methods: We conducted a retrospective analysis of 128 patients who received BoNT in our Neurology clinic during an 11-year period (January 2003 to December 2014). All patients received BoNT type A injections.

Results: A total of 858 injections of BoNT were administered to 128 patients. Seventy (54.7\%) patients with hemifacial spasm had 456 injection sessions, 24 (18.8\%) patients with blepharospasm had 209 injection sessions, 21 (16.4\%) patients with cervical dystonia had 145 injection sessions, 8 (6.3\%) patients with spasticity had 29 injection sessions, $3(2.3 \%)$ patients with migraine-type headache had 14 injection sessions, $1(0.8 \%)$ patient with sialorrhea had 3 injection sessions, and $1(0.8 \%)$ patient with upper-extremity dystonia underwent 2 injection sessions. The mean onset of effects after injection was $7.11 \pm 2.34$ days, the duration of effect was $13.0 \pm 5.46$ weeks, and the amount of improvement was $61.5 \pm 16.7 \%$ in all patients. A total of $27(3.14 \%)$ adverse effects were recorded in 858 injection sessions. The adverse effects were mild and tolerable.

Conclusion: Our results show that BoNT type A is an effective and safe therapy for various types of neurologic conditions.

Keywords: Botulinum toxin, efficacy, safety

\section{$\ddot{\mathbf{O z}}$}

Amaç: Çalışmanın amacı çeşitli nörolojik hastalıkların tedavisinde kullanılan Botulinum toksini (BoNT) ile olan deneyimlerimizi bildirmektir.

Gereç ve Yöntem: Nöroloji kliniğimizde 11 yıllık periyotta (Ocak 2003-Aralık 2014) takip edilen ve BoNT tip A enjeksiyonu uygulanmış olan 128 hasta retrospektif olarak incelendi.

Bulgular: İncelenen 128 hastaya toplam 858 seans BoNT uygulanmışı. Bunlar arasında, 456 seans uygulama yapılan 70 (\%54,7) hastada hemifasyal spazm, 209 seans uygulama yapilan $24(\% 18,8)$ hastada blefarospazm, 145 seans uygulama yapılan $21(\% 16,4)$ hastada servikal distoni, 29 seans uygulama yapılan $8(\% 6,3)$ hastada spastisite, 14 seans uygulama yapılan $3(\% 2,3)$ hastada migren tipi baş ağrısı, 3 seans uygulama yapılan $1(\% 0,8)$ hastada siyalore ve 2 seans uygulama yapılan $1(\% 0,8)$ hastada üst ekstremite distonisi mevcuttu. Çalışma popülasyonunda enjeksiyon sonrası ortalama etki başlangıc1 $7,11 \pm 2,34$ gün, ortalama etki

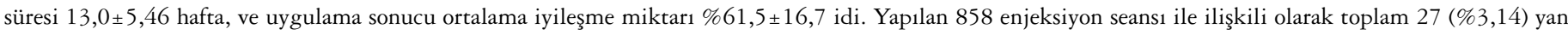
etki kaydedildi. Yan etkilerin tümü hafif ve tolere edilebilirdi.

Sonuç: Sonuçlarımız BoNT tip A tedavisinin birçok nörolojik hastalıkta etkili ve güvenli bir tedavi yöntemi olduğunu göstermektedir.

Anahtar Kelimeler: Botulinum toksini, etkinlik, güvenilirlik 


\section{Introduction}

Botulinum toxin (BoNT) is a potent exotoxin produced by the anaerobic bacteria Clostridium Botulinum. The light chain endopeptidase component of BoNT acts on the end plate of motor neurons where it cleaves Synaptosomal-associated protein-25, a protein involved in the fusion of acetylcholine-containing vesicles with the presynaptic membrane. The toxin enables neuromuscular blockade by preventing acetylcholine secretion from the presynaptic vesicles, which causes temporary denervation (1). Also, BoNT injected peripherally might influence central nervous system function (2). Denervation of intrafusal muscle fibers by blocking gamma and alpha motor neurons decreases muscle spindle afferent input to the central nervous system and thus modifies sensorimotor and proprioceptive pathways $(3,4,5)$. There are various types of BoNT in nature, and among these, type-A toxin is the most stable and commercially used for medical treatment (6).

The therapeutic use of BoNT in humans was first tested for the treatment of strabismus in 1977 (7). Later, BoNT began to be used as a treatment for movement disorders including blepharospasm (BPS), hemifacial spasm (HFS), and cervical dystonia (CD) $(8,9,10)$. The United States Food and Drug Administration approved BoNT type A for the treatment of strabismus, BPS, and HFS in 1989, and for CD in 1990. Since then, other formulations of different types of BoNT have been developed for commercial use and these are used to treat various clinical disorders. Migraine and spasticity are also indications of BoNT in neurology practice (11).

It is important to collect information about the safety and efficacy of treatment with BoNT because of its widespread use. Therefore, the aim of this study was to describe our 11-year experience in various neurologic conditions in a tertiary center in Turkey.

\section{Materials and Methods}

This retrospective study included 128 patients (70 with HFS, 24 with BPS, 21 with CD, 8 with spasticity, 3 with chronic migrainetype headache, 1 with sialorrhea, and 1 with upper-extremity dystonia) who were admitted to the BoNT Outpatient Clinic of the Department of Neurology, Faculty of Medicine, Süleyman Demirel University, between January 2003 and December 2014. The study was approved by the Süleyman Demirel University Department of Medical Sciences Ethics Committee. Patients who received two or more injections of BoNT type A and were followed up for at least one year were included in the study. Patients who were treated with neuroleptics or other drugs that interfere with neuromuscular transmission such as aminoglycosides and spectinomycin, and who had incomplete medical records were excluded from the study. Detailed history was obtained for all patients before injections and all patients underwent a thorough physical and neurologic examination, and investigations for any differential diagnosis that may need therapeutic management other than BoNT type A injections. At each injection session, patients were asked about the results of the previous injection session. Information about the mean onset of effect, mean duration of effect, mean doses of BoNT type A, amount of improvement, and adverse effects for each administration were recorded. The amount of improvement was assessed by the patients as percentages ranging from $0 \%$ to $100 \%$ using a visual analogue scale (VAS); $0 \%$ represented a total lack of improvement and $100 \%$ represented full improvement with return to normal function. These data were affirmed with clinical history and physical examination on each visit. The dates of all BoNT type A follow-up visits between the first and last injection visits were also recorded. BoNT type A injections were performed with at least a three-month interval in our clinic. The intervals could be longer according to diagnosis, availability of appointments, and the duration of effect observed on the previous injections.

We used 100 IU BoNT type A (Botox, Allergan) diluted with $2 \mathrm{~mL}$ of sterile saline. The usual dilution of BoNT type A was $5 \mathrm{IU}$ per $0.1 \mathrm{~mL}$. Each treatment cycle consisted of multiple injections into single or multiple muscles. The injections in some applications were performed under electromyographic guidance whenever necessary. The dose for the subsequent injections was modified according to the therapeutic response.

Statistical analysis was performed using Statistical Package for Social Sciences version 15.0. Data were presented as mean \pm standard deviation. The normality of the distribution for all variables was assessed using the Kolmogorov-Smirnov test. Categorical variables were compared among the groups using the Chi-square test. One-Way ANOVA or Kruskal-Wallis test were used for inter-group comparisons. $\mathrm{P}<0.05$ was considered statistically significant.

\section{Results}

A total of 858 injections of BoNT type A were administered to 128 patients over an 11 -year period. The $70(54.7 \%)$ patients with HFS had 456 injection sessions, 24 (18.8\%) patient with BPS had 209 injection sessions, $21(16.4 \%)$ patients with CD had 145 injection sessions, $8(6.3 \%)$ patients with spasticity due to stroke or cerebral palsy had 29 injection sessions, $3(2.3 \%)$ patients with migraine-type headache had 14 injection sessions, 1 $(0.8 \%)$ patient with sialorrhea underwent 3 injection sessions, and $1(0.8 \%)$ patient with upper-extremity dystonia had 2 injection sessions. Seventy-four $(57.8 \%)$ patients in the study were women and fifty-four (42.2\%) patients were men and their mean age was $58 \pm 16.6$ years. The patients' mean follow-up time was $3.64 \pm 2.83$ years. The demographic data of the patients are summarized in Table 1.

The mean BoNT injection dose was $66.5 \pm 135.81$ units per session and the mean BoNT injection dose was $15.7 \pm 4.80$ for HFS, $31.0 \pm 11.7$ for BPS, $171.28 \pm 63.13$ for CD, $188.68 \pm 43.07$ for spasticity, $64.9 \pm 23.0$ for migraine, 30 for sialorrhea and 150 for upper-extremity dystonia. The mean onset of effect after the injection was $7.11 \pm 2.34$ days, duration of effect was $13.0 \pm 5.46$ weeks, and amount of improvement of applications was $61.5 \pm 16.7 \%$ in all patients. The treatment results according to the conditions are summarized in Table 2 . The amount of improvement of applications and mean onset of effect after the injection were not statistically different among the conditions $(\mathrm{p}=0.20, \mathrm{p}=0.10$, respectively). The mean duration of effect was statistically different among the conditions $(p=0.006)$. The patients with $C D$ had longer mean duration of effect compared with the patients with HFS and BPS ( $\mathrm{p}=0.001, \mathrm{p}=0.001$, respectively). Also, the patients with HFS had longer mean duration of effect than the patients 
with BPS ( $\mathrm{p}=0.02)$. Adverse effects were observed in $17(13.3 \%)$ patients diagnosed with HFS, BPS or CD. A total of $27(3.14 \%)$ adverse effects were recorded in 858 injection sessions. Details of the adverse events are summarized in Table 3. We did not find any statistical difference among the patients with HFS, BPS, and CD in terms of the presence of adverse effects $(p=0.88)$.

\section{Discussion}

BoNT has been used in numerous neurologic conditions such as dystonia, spasticity, headaches and other painful disorders, HFS, motor tics, essential tremor, hyperhidrosis, and sialorrhea (11). In this study, we retrospectively analyzed the treatment results of 128 patients with various neurologic conditions. The patients received a total of 858 BoNT type A injection sessions over an 11-year period. The amount of improvement was $61.5 \%$ in all patients. In total, $3.14 \%$ adverse effects were recorded in 858 injection sessions and all adverse effects were local, mild, and well tolerated. We found that BoNT type A was a safe and effective treatment for these conditions.

\begin{tabular}{|lllll|}
\hline \multicolumn{7}{|c|}{ Table 1. Demographic data of the patients } \\
n (\%) & $\begin{array}{l}\text { Age* (year) } \\
\text { mean } \pm \text { SD }\end{array}$ & $\begin{array}{l}\text { Gender } \\
\text { M/F (N) }\end{array}$ & $\begin{array}{l}\text { Follow-up } \\
\text { (year) } \\
\text { mean } \pm \text { SD }\end{array}$ \\
HFS & $70(54.7)$ & $61.6 \pm 13.2$ & $26 / 44$ & $3.20 \pm 2.64$ \\
BPS & $24(18.8)$ & $65.2 \pm 14.3$ & $10 / 14$ & $4.20 \pm 2.57$ \\
CD & $21(16.4)$ & $52.8 \pm 16.0$ & $10 / 11$ & $5.09 \pm 3.60$ \\
Spasticity & $8(6.3)$ & $32.0 \pm 15.4$ & $5 / 3$ & $2.62 \pm 2.26$ \\
Migraine & $3(2.3)$ & $42.6 \pm 6.80$ & $1 / 2$ & $3.00 \pm 1.73$ \\
$\begin{array}{l}\text { Sialorrhea } \\
\begin{array}{l}\text { Upper- } \\
\text { extremity }\end{array}\end{array}$ & $1(0.8)$ & 22.0 & $1 / 0$ & $4.00 \pm 0.0$ \\
dystonia & & 26.0 & $1 / 0$ & $1.00 \pm 0.0$ \\
$\begin{array}{l}\text { HFS: Hemifacial spasm, BPS: Blepharospasm, CD: Cervical dystonia, F: Female, } \\
\text { M: Male, N: Number of patients, SD: Standard deviation, *Age of the patients } \\
\text { at the last visit }\end{array}$ \\
\hline
\end{tabular}

\begin{tabular}{|c|c|c|c|c|}
\hline & $\mathrm{n}$ & $\begin{array}{l}\text { Onset of } \\
\text { effect }^{*} \\
(\text { days }), \\
\text { mean } \pm \text { SD }\end{array}$ & $\begin{array}{l}\text { Duration } \\
\text { of effect } \\
\text { (weeks), } \\
\text { mean } \pm \text { SD }\end{array}$ & $\begin{array}{l}\text { Amount of } \\
\text { improvement } \\
(\%), \\
\text { mean } \pm \text { SD }\end{array}$ \\
\hline HFS & 456 & $7.09 \pm 2.04$ & $12.6 \pm 4.78$ & $64.3 \pm 16.7$ \\
\hline BPS & 209 & $6.17 \pm 1.66$ & $11.3 \pm 5.57$ & $56.2 \pm 17.5$ \\
\hline $\mathrm{CD}$ & 145 & $8.26 \pm 3.69$ & $16.2 \pm 6.04$ & $61.7 \pm 14.0$ \\
\hline Spasticity & 29 & $7.08 \pm 1.27$ & $13.8 \pm 8.08$ & $54.0 \pm 20.3$ \\
\hline Migraine & 14 & $6.76 \pm 1.07$ & $12.4 \pm 1.85$ & $60.3 \pm 13.0$ \\
\hline Sialorrhea & 3 & $9.50 \pm 0.70$ & $13.5 \pm 0.70$ & $65.0 \pm 7.07$ \\
\hline $\begin{array}{l}\text { Upper- } \\
\text { extremity } \\
\text { dystonia }\end{array}$ & 2 & $6.00 \pm 0.00$ & $13.0 \pm 0.00$ & $45.0 \pm 7.07$ \\
\hline
\end{tabular}

In our study, HFS was the most common diagnosis. HFS is a chronic condition that rarely remits spontaneously. It significantly disfigures the face and thereby causes an important social handicap for patients and complicates social fulfillment and communication (12). BoNT type A plays an important role in the treatment of HFS because the recommended drugs usually have poor, brief, or no effect, and frequent adverse effects. Therefore, BoNT type A should be considered as the first-line therapy in patients with HFS (13). Barbosa et al. (14) retrospectively evaluated 54 patients with HFS who underwent a total of 808 injections. The researchers found that the mean duration of improvement per application was 3.46 months and the mean rate of improvement was of $83 \%$. Adverse effects developed in $64.8 \%$ of patients at least once during the follow-up period and the most common adverse effect was orbicularis oris paralysis (38.8\%) in their study. Jost and Kohl (15) reported 6698.6\% improvement rate and the mean effect duration of 2-3.5 months in patients with HFS. In another study, the therapeutic effect started 3 to 5 days after the injection and the complication rate was $7.29 \%$ in HFS (ptosis, ecchymosis of the injected region, and lower facial weakness) (16). Kwan et al. (17) reported that there was a $10 \%$ complication rate in 170 patients with HFS and the researchers suggested that BoNT treatment was safe.

BPS is a focal dystonia characterized by involuntary forceful eye closure and impaired opening of the eyes due to spasmodic contractions that involve the following muscles; orbicularis oculi, corrugators, procerus, and levator palpebrae. BPS substantially limits work capability, results in functional blindness, reduces a patient's quality of life, and requires long-term treatment. BoNT is currently the most common treatment modality in BPS (12). Silveira-Moriyama et al. (18) analyzed a total of 379 treatments with BoNT type A in 30 patients with BPS. They reported that the mean duration of improvement was 2.64 months, $93 \%$ of the patients exhibited considerable improvement after the first BoNT injection, and adverse effects, which were commonly minor, developed at least once in $53 \%$ of patients in their study. Taylor et al. (19) expressed that BoNT type A significantly reduced symptoms in 235

\begin{tabular}{|lll|}
\hline \multicolumn{3}{|c|}{ Table 3. Adverse effects in the patients } \\
HFS & $\mathrm{n}=70$ & $\mathrm{n}=456$ \\
Oral asymmetry & 7 & 14 \\
Ptosis & 3 & 5 \\
Ecchymosis & 1 & 1 \\
Total & $11(15.7 \%)$ & $20(4.38 \%)$ \\
BPS & $\mathrm{n}=24$ & $\mathrm{n}=209$ \\
Ptosis & 2 & 2 \\
Ecchymosis & 1 & 1 \\
Total & $3(12.5 \%)$ & $3(1.43 \%)$ \\
CD & $\mathrm{n}=21$ & $\mathrm{n}=145$ \\
Dysphagia & 2 & 3 \\
Neck weakness & 1 & 1 \\
Total & $3(14.2 \%)$ & $4(2.75 \%)$ \\
HFS: Hemifacial spasm, BPS: Blepharospasm, CD: Cervical dystonia \\
\hline
\end{tabular}


patients with BPS and in 130 patients with HFS during over 5-year period. In another study, it was reported that a beneficial effect of the injections was seen within 48 hours in all patients with BPS; there were minor adverse effects such as irritation in the eyes and heaviness in the brow region, and one $(5.88 \%)$ patient developed mild ptosis (20). Drummond and Hinz reported that the mean duration of efficacy was 15 weeks for patients with HFS, and 12 weeks for patients with BPS (21). Ramirez-Castaneda and Jankovic (22) found that ptosis was the most frequent adverse effect $(33.7 \%)$ in patients with BPS. Gil Polo et al. (23) retrospectively analyzed 89 patients with BPS or HFS during the treatment with BoNT type $A$. The researchers found that the most frequent adverse effect was ptosis (47.1\% in BPS, $32.5 \%$ in HFS). Snir et al. (24) reported minor and temporary adverse events; dry eye (70.4\%), ptosis $(7.4 \%)$, and diplopia $(7.4 \%)$. In our study, the onset of effect was $7.09 \pm 2.04$ days in HFS and $6.17 \pm 1.66$ days in BPS; the duration of effect was $12.6 \pm 4.78$ weeks in HFS and $11.3 \pm 5.57$ weeks in BPS, and the amount of improvement was $64.3 \pm 16.7 \%$ in HFS and $56.2 \pm 17.5 \%$ in BPS. We found minor adverse effects in patients with HFS and BPS. In the present study, the complication rate was $4.38 \%$ among 456 injection sessions in HFS, most frequently oral asymmetry $(3.07 \%)$, followed by ptosis $(1.09 \%)$ and ecchymosis of the injected region $(0.21 \%)$. In BPS, the complication rate was $1.43 \%$ in 209 injection sessions, which were mostly ptosis $(0.95 \%)$, followed by ecchymosis of the injected region $(0.47 \%)$. The lower ptosis rate in our study may be due to administration to the pretarsal of the orbicularis oculi muscle and using only one preparation. Also, it may be due to that especially at $5 \mathrm{IU}$ or above dosage, at first we injected a part of the dosage to the lateral of the injection site in pretarsal of the orbicularis oculi muscle and then we applied the remaining dosage after pulling the needle back slightly. Lower rate of oral asymmetry in this study may be due to avoiding injections to the lower face and using lower doses if not necessary. Cakmur et al. (25) compared pretarsal injections with preseptal injections in 25 patients with BPS and 28 patients with HFS. The authors detected elevated response rates and longer effect duration in patients who received pretarsal injections. Ptosis was the most frequent adverse effect in both groups, which was less common in the pretarsal injection group compared with the preseptal injection group. Our findings in HFS and BPS are consistent with those in earlier studies $(18,19,20,21)$.

$\mathrm{CD}$ is the most common form of adult-onset focal dystonia. BoNT injection been reported as the first-line therapy for CD (26). There are several studies regarding the efficacy and safety profile of BoNT injections for the treatment of CD $(27,28,29)$. Şen et al. (27) evaluated 57 patients with CD retrospectively and reported that the mean latency to response was $6.11 \pm 4.78$ days, the mean peak improvement time was $13.24 \pm 6.30$ days, and the mean duration of effect of BoNT-A treatment was $13.02 \pm 4.61$ weeks. The researchers found that the most frequent adverse effect was dysphagia (40\%), followed by atrophy of some treated muscles $(11.11 \%)$, weakness in cervical muscles $(11.11 \%)$, syncope $(4.44 \%)$, hoarseness $(2.22 \%)$, and hypophonia (2.22\%). In the Bhaumik and Behari (28) study, the mean latency to response was $9.7 \pm 5.7$ days. In another study, this period was $11 \pm 1.6$ weeks (26). Skogseid and Kerty (29) analyzed 78 patients with $\mathrm{CD}$ who were treated with onabotulinum toxin type $A$ and found improved median difference of 4.0 on a 1-8 VAS. Ramirez-Castaneda and Jankovic (22) reported that adverse events accounted for $10 \%$ of all patients' visits for CD; dysphagia (27.1\%) and neck muscle weakness $(17.1 \%)$ were the most common adverse events in patients with CD in their patient cohort. In our study, the mean onset of effect was $8.26 \pm 3.69$ days, duration of effect was $16.2 \pm 6.04$ weeks, and the amount of improvement was $61.7 \pm 14.0 \%$ in patients with $\mathrm{CD}$. The patients with $\mathrm{CD}$ had longer duration of effect compared with the patients with HFS and BPS in our study. The complication rate was $2.75 \%$ in 145 injection sessions in $\mathrm{CD}$, most frequently with dysphagia (2.06\%), followed by neck weakness $(0.68 \%)$. Dysphagia and neck weakness rate was lower in our study. This is probably because we did not inject bilaterally and overdose unless necessary and some injections were performed under electromyographic guidance, in deep muscles in particular.

BoNT type A has been used to manage other neurologic conditions such as spasticity in patients with variety of underlying etiologies, migraine-type headache, sialorrhea, and limb dystonia $(11,30)$. In our study, the minority of the patients had spasticity due to stroke or cerebral palsy, chronic migraine, sialorrhea, and limb dystonia. These patients showed therapeutic benefit with BoNT type A. Adverse effects did not occur in these patients perhaps because the total number of subjects in each type of these conditions was low and we performed the injections under electromyographic guidance for some cases of spasticity and limb dystonia.

Several limitations of the present study should be considered. These include the small number of patients in some neurologic conditions, the predominance of patients with HFS, and the unequal follow-up periods among patient groups. This study was not a doubleblind, controlled study. The retrospective design and the rater bias were also limitations of this study. Additionally, the patients were treated with only one brand of BoNT type A, as mentioned earlier. Therefore, we could not compare the results with distinct brands. Despite these limitations, we think that our findings contribute to the literature because our study group consisted of a heterogeneous patient group and large numbers of patients.

\section{Conclusion}

In conclusion, BoNT type A treatment is safe and effective for patients with HFS, BPS, CD, spasticity, chronic migraine-type headache, sialorrhea, and upper-extremity dystonia, each of which affects patients' quality of life. This safety and efficiency make it a valuable treatment option in the management of these conditions. The effect of BoNT is temporary and repeated injections are required. The application of BoNT type A injection is simple and it can be performed in the outpatient clinic.

\section{Ethics}

Ethics Committee Approval: The study was approved by the Süleyman Demirel University of Local Ethics Committee.

Peer-review: Externally peer-reviewed.

\section{Autborship Contributions}

Surgical and Medical Practices: Hasan Rıfat Koyuncuoğlu, Seden Demirci, Concept: Hasan Rıfat Koyuncuoğlu, Seden Demirci, Design: Hasan Rıfat Koyuncuoğlu, Seden Demirci, Data Collection or Processing: Hasan Rıfat Koyuncuoğlu, Seden Demirci, Analysis or Interpretation: 
Hasan Rıfat Koyuncuoğlu, Seden Demirci, Literature Search: Seden Demirci, Writing: Seden Demirci. Conflict of Interest: No conflict of interest was declared by the authors, Financial Disclosure: The authors declared that this study has received no financial support.

\section{References}

1. Thenganatt MA, Fahn S. Botulinum toxin for the treatment of movement disorders. Curr Neurol Neurosci Rep 2012;12:399-409.

2. Gracies JM. Physiological effects of botulinum toxin in spasticity. Mov Disord 2004;19:120-128.

3. Giladi N. The mechanism of action of Botulinum toxin type A in focal dystonia is most probably through its dual effect on efferent (motor) and afferent pathways at the injected site. J Neurol Sci 1997;152:132-135.

4. Hallett M. How does botulinum toxin work? Ann Neurol 2000;48:7-8.

5. Rosales RL, Dressler D. On muscle spindles, dystonia and botulinum toxin. Eur J Neurol 2010;17:71-80.

6. Waller RR, Kennedy RH, Henderson JW, Kesty KR. Management of blepharospasm. Trans Am Ophthalmol Soc 1985;83:367-386.

7. Scott $\mathrm{AB}$. Botulinum toxin injection into extraocular muscles as an alternative to strabismus surgery. Ophthalmology 1980;87:1044-1049.

8. Tsui JK, Elsen A, Mak E, Carruthers J, Scott A, Calne DB. A pilot study on the use of botulinum toxin in spasmodic torticollis. Can J Neurol Sci 1985;12:314-316

9. Scott $A B$, Kennedy RA, Stubbs HA. BotulinumA toxin injection as a treatment for blepharospasm. Arch Ophthalmol 1985;103:347-350.

10. Brin MF, Fahn S, Moskowitz C, Friedman A, Shale HM, Greene PE, Blitzer A, List T, Lange D, Lovelace RE, et al. Localized injections of botulinum toxin for the treatment of focal dystonia and hemifacial spasm. Mov Disord 1987;2:237-254.

11. Lim EC, Seet RC. Use of botulinum toxin in the neurology clinic. Nat Rev Neurol 2010;6:624-636.

12. Streitova H, Bares M. Long-term therapy of benign essential blepharospasm and facial hemispasm with botulinum toxin A: Retrospective assessment of the clinical and quality of life impact in patients treated for more than 15 years. Acta Neurol Belg 2014;114:285-291.

13. Kenney C, Jankovic J. Botulinum toxin in the treatment of blepharospasm and hemifacial spasm. J Neural Transm 2008;115:585-591.

14. Barbosa ER, Takada LT, Gonçalves LR, Costa RM, Silveira-Moriyama L, Chien HF. Botulinum toxin type A in the treatment of hemifacial spasm: an 11-year experience. Arq Neuropsiquiatr 2010;68:502-505.

15. Jost WH, Kohl A. Botulinum toxin: Evidence based medicine criteria in blepharospasm and hemifacial spasm. J Neurol 2001;248:21-24.
16. Çabalar M, Yayla V, Çulha A, Selçuk Ö. Efficacy and Safety of Botulinum Toxin Type A (Botox $\left.{ }^{\circledR}\right)$ in Blepharospasm and Hemifacial Spasm. Turkiye Klinikleri J Med Sci 2013;33:1231-1235.

17. Kwan MC, Ko KF, Chan TP, Chan YW. Treatment of dystonia with botulinum A toxin: A retrospective study of 170 patients. Hong Kong Med J 1998;4:279-282.

18. Silveira-Moriyama L, Gonçalves LR, Chien HF, Barbosa ER. Botulinum toxin $\mathrm{A}$ in the treatment of blepharospasm: A 10-year experience. Arq Neuropsiquiatr 2005;63:221-224.

19. Taylor JD, Kraft SP, Kazdan MS, Flanders M, Cadera W, Orton RB. Treatment of blepharospasm and hemifacial spasm with botulinum A toxin: a Canadian multicentre study. Can J Ophthalmol 1991;26:133-138.

20. Anwar MS, Zafar H. Efficacy of botulinum toxin in benign essential Blepharospasm: Desirable \& undesirable effects. Pak J Med Sci 2013;29:1389-1393.

21. Drummond GT, Hinz BJ. Botulinum toxin for blepharospasm and hemifacial spasm: stability of duration of effect and dosage over time. Can J Ophthalmol 2001;36:398-403.

22. Ramirez-Castaneda J, Jankovic J. Long-term efficacy, safety, and side effect profile of botulinum toxin in dystonia: A 20-year follow-up. Toxicon 2014;90:344-348

23. Gil Polo C, Rodríguez Sanz MF, Berrocal Izquierdo N, Castrillo Sanz A, Gutiérrez Ríos R, Zamora García MI, Mendoza Rodríguez A, Duarte GarcíaLuis J. Blepharospasm and hemifacial spasm: Long-term treatment with botulinum toxin. Neurologia 2013;28:131-136.

24. Snir M, Weinberger D, Bourla D, Kristal-Shalit O, Dotan G, Axer-Siegel $\mathrm{R}$. Quantitative changes in botulinum toxin A treatment over time in patients with essential blepharospasm and idiopathic hemifacial spasm. Am J Ophthalmol 2003;136:99-105.

25. Cakmur R, Ozturk V, Uzunel F, Donmez B, Idiman F. Comparison of preseptal and pretarsal injections of botulinum toxin in the treatment of blepharospasm and hemifacial spasm. J Neurol 2002;249:64-68.

26. Mohammadi B, Buhr N, Bigalke H, Krampfl K, Dengler R, Kollewe K. A long-term follow-up of botulinum toxin A in cervical dystonia. Neurol Res 2009;31:463-466

27. Şen A, Soysal A, Arpacı B. Clinical characteristics and response to longterm botulinum toxin type A therapy in patients with cervical dystonia at a neurology clinic. Archives of Neuropsychiatry 2014;51:383-388.

28. Bhaumik S, Behari M. Botulinum toxin A-injection for cervical dystonia. J Assoc Physicians India 1999;47:267-270.

29. Skogseid IM, Kerty E. The course of cervical dystonia and patient satisfaction with long-term botulinum toxin A treatment. Eur J Neurol 2005;12:163-170.

30. Ramachandran R, Yaksh TL. Therapeutic use of botulinum toxin in migraine: Mechanisms of action. Br J Pharmacol 2014;171:4177-4192. 